\title{
Reading at the Threshold: The Role of Illustrations in the Reception of the Early Editions of Celestina
}

\author{
Ana Isabel Montero \\ Willamette University
}

In the last half of the fifteenth century, the introduction of printing, in a rapid but blurred passage between pen and press production, marks the advent of modernity. This decisive transition in European culture had a definitive impact in the coexistence of visual and verbal texts on the illuminated page. Standing at this threshold between the manuscript and the print culture, the first known edition of the Comedia de Calisto and Melibea brought in the quintessentially liminal figure of Celestina, whose name has come to be synonymous with go-between in Iberian cultural tradition. Placed at the center of the page, the woodcuts of the 1499(?) edition constitute a key element in the widespread recognition attained by both the book and its main character. This article will examine the early editions, translations, and adaptations of Celestina, the Comedia, and later the Tragicomedia, as a means to learn about the reception of the initial edition and how the woodcuts became indispensable to its transmission, to the point that most of the immediately subsequent printers and editors "read» the illustrations as part of the text.

According to reception theory, the meaning of a text is never static or autonomous, but rather constantly mutating as it enters into contact with the reader and the historical context in which she is immersed. Wolfgang Iser defines the act of reading as a process of actualization, a dialogue between the text and the reader in which the meaning of the text is constantly negotiated and re-created. Like a chess game, this bilateral negotiation is to be conducted under a certain set of rules or predetermined strategies, i.e., the guidelines established by the social, historical, vital, and cultural contexts that determine the "basic conditions of interaction" (Iser 107). According to Iser, in this dialectic the reader plays the leading role, since she "sets in motion" the very process of actualization (106). Of course, the absence of one of the interlocutors in this literary conversation - accentuated when there is a significant chronological lapse 
between reader and text - creates a "constitutive blank» that, instead of cutting communication, stimulates it, as it demands to be filled by the reader's active interpretation. Naturally, this process is not completely arbitrary, since the text provides the basic frame. In the course of the act of reading, a window opens, revealing certain textual possibilities, but also closes, excluding others in a dynamic process of «mutually restrictive and magnifying interaction between the implicit and the explicit, between revelation and concealment» (Iser 111). During the act of reading, the reader "passes through various perspectives offered by the text» in a dynamic process: the event of crossing the threshold from virtual to actual text in the process of actualization (Iser 106). Far from the traditional search of the one true meaning hidden deep in the text, this process stimulates a polysemic hermeneutics. In the course of filling the gap of signification, the reader is not likely to exhaust the almost bottomless well of potential meanings that may arise from this productive friction between reader and text and their respective contexts (Iser 111-13).

For medieval psychology, the process of reading and the process of viewing were tightly intertwined because there was not a drastic separation between written and visual text. Images were necessary instruments for human cognition in the process of textual elucidation. When it came to reading, the medieval understanding of imagination and thought engaged in "a mental processing of texts into images, which [...] in turn, [formed] the basis of literary re-creation" (Folger 15). ${ }^{1}$ Accordingly, the medieval act of reading cannot be isolated from this written-visual interaction, and $\mathrm{Ce}$ lestina's illustrations should be taken into account when exploring the possibilities of actualization of the wide semantic potential of Rojas's work.

From a diachronic perspective, Hans R. Jauss expands the two-way interaction between reader and text by including the historical, cultural, and literary influences that antecede and precondition textual reception. Following Jauss's Rezeptionstheorie, the reader's individual approach to the text cannot be isolated, since it is predetermined and prejudged by other works, other readers, and other experiences of reading that configure the literary and critical panorama, and draw an horizon of expectations that «arises from each work, in the historical moment of its appearance from a pre-understanding of the genre, from the form and themes of already familiar works, and from the opposition between poetic and practical language» $(22){ }^{2}$

1.- For an extensive analysis of medieval faculty psychology, see Folger (15-81). Robert Folger states that the rudiments of this psychological theory were available in Iberia in the vernacular at least from the thirteenth century (as attested in Alfonso X's Siete Partidas) and that these ideas continued to be relevant until the sixteenth century (28).

2.- As Paul de Man points out in his introduction to Jauss's book, this horizon of expectations «mediates between the private inception and the public reception of the work» (Toward an Aesthetic xiii). 
Far from being fixed or perennial, this horizon of expectations transforms over time. In the case of Celestina's audience, its horizon of expectations has significantly evolved since the first edition of the Comedia (1499?). At least until the middle of the sixteenth century, illustrations played an essential role in the dissemination of this work and were a key element in the aesthetic experience of its reception. Chronologically, the first trace of the reception of Rojas's work can be found in the conversion of the Comedia into Tragicomedia due to popular and editorial demand. ${ }^{3}$ In the prologue to the first edition of the Tragicomedia (1502), Rojas alluded to the contienda or controversy created after the successful publication of the Comedia. The controversy involved not only the moral intention of the book, but also its designation as comedy: "Otros han litigado sobre el nombre, diziendo que no se avía de llamar comedia, pues acabava en tristeza, sino que se llamase tragedia» (81). This debate concluded with the change of the title to Tragicomedia, as Rojas admits, in an attempt to end the disputes: "Yo, viendo estas discordias, entre estos extremos partí agora por medio la porfía, y llaméla tragicomedia» (81). In addition to changing the title, Rojas also inserted the five acts included in the "Tratado de Centurio.» The additions introduced a new character, the humorous Centurio, perhaps in an attempt to build up the comic aspect of the work, as well as one more sexual encounter between Calisto and Melibea, in response to the readers' persistent request. ${ }^{4}$ As Rojas acknowledges in his prologue,

Assí que viendo estas contiendas, estos díssonos y varios juyzios, miré a donde la mayor parte acostava, y hallé que querían que alargasse en el proceso de su deleyte destos amantes, sobre lo cual fuy muy importunado, de manera que acordé, aunque contra mi voluntad, meter segunda vez la pluma en tan estraña lavor y tan agena de mi facultad... $(81)^{5}$

3.- As Emilio Blanco points out, the first reader was allegedly Rojas, if we trust that he did not write the first auto (18).

4.- In the foreword to his work, Towards a Critical Edition of the Celestina, J. Homer Herriot notes, "when the book was published some critics were of the opinion that the love affair it recounted moved forward too rapidly» (v).

5.- It is very interesting the wording chosen by Rojas to describe the undertaking of his additional writing in the Tragicomedia. He uses the expression «meter segunda vez la pluma,» which literally means "to stick in the pen for the second time.» There is no need to explain the obvious phallic implications of this metaphor, which becomes even more intricate if we consider that this addition will also introduce a second erotic encounter for the lovers, i.e., a second act of penetration of Melibea's body. Considering the sexual implications, it seems almost ironic that Rojas states that he does it against his will. 
In these lines, Rojas protests that he was forced by the insistence of the audience to introduce this new writing. ${ }^{6}$ This complaint must be taken, however, with a grain of salt, since the author might be using the public insistence as an excuse to protect himself from the potential censorship or inquisitorial scrutiny of this expansion in the erotic description. These additions in response to the audience's reception also included new illustrations, which attest to the importance of the images in the diffusion of the book. This could be an attempt to secure the success of the new version by enhancing the visual dimension, therefore implicitly acknowledging the role of the illustrations in the initial success of the work.

Once the initial contiendas were addressed and shortly after the first known edition of the Comedia, the Tragicomedia was translated into Italian (1505), beginning the innumerable list of versions and translations. As Whinnom points out, Rojas' masterpiece was an unprecedented best seller from the very first decades after its composition ("The Problem of the Best-Seller» 166). According to J. Homer Herriot, there were around sixty editions published before 1530, although most of them are now lost. ${ }^{7}$ Penney also lists sixteen translations (into English, French, Italian, and German) prior to that year, which gives us an idea of the swift geographical dissemination of the work from the earliest moments of its inception (114-21).

The first French translation was published in 1527. As Snow notes, this edition is fully illustrated, and a woodcut opens every act, following the scheme of the 1499(?) edition ("The Iconography» 28). Unlike Fadrique's Comedia, in the French translation the illustrations consist of pairs of tacos [stock pieces or factotum blocks], each portraying a character, which is identified by a caption scroll located above it. This much less sophisticated approach to illustration may respond to the urgent need for new editions owing to the swift success achieved by the Spanish version. This shows that, no matter how rudimentary, illustrations had become a crucial part of the work and its marketability. As Clive Griffin points out, given the high cost of paper at the time, there must have been a strong commercial reason behind the inclusion of so many illustrations. Griffin calls attention to the fact that editors, despite the cost of illustrating $\mathrm{Ce}$ lestina, once it became standard to illustrate it, could not afford not to do so. This had to do with the popularity of the work in the competitive

6.- On this subject, Emilio Blanco points out that the printers can be counted among the first readers of Rojas's work and certainly some of the most influential (28-31). In the prologue to the 1502 edition, Rojas complained of the puncturas that the printers had inflicted on his work by inserting the argumentos. There is also a certain resemblance between the aforementioned act of «meter la pluma,» which can be graphically envisioned as a puncture or perforation in the material body of the text, and the puntura of the iron hinges of the printing press, symbolizing the violence that the printers did to the text in the name of commercial interests.

7.- Critics disagree on this point. Frederick Norton, for instance, gives the same number of editions, but for the whole sixteenth century (101). 
market of early printers where "each had to ensure that his editions were particularly attractive to potential buyers, and the inclusion of woodcuts served that purpose» (Griffin 60). It is also clear how influential the 1499(?) edition was, since the following editions in the fifteenth and sixteenth century seem to have been modeled after it, to a greater or lesser extent.

In Portugal, the diffusion of Celestina was equally important, even before the publication of the first Portuguese edition - printed in 1540 in Spanish. In this case, we can find evidence of a visual history in the transmission of Rojas's work that preceded the actual printing. As Dean $\mathrm{McPheeters} \mathrm{notes,} \mathrm{among} \mathrm{the} \mathrm{wedding} \mathrm{presents} \mathrm{given} \mathrm{to} \mathrm{princess} \mathrm{Be-}$ atrice for the occasion of her nuptials with the duke of Savoy (1521), there was a silver mug with the story of Celestina engraved on it. Another piece of evidence would be a sixteenth-century Portuguese lace bedspread with scenes from the Tragicomedia, and the names of Sempronio, Melibea and Celestina embroidered on it, preserved at the Victoria and Albert Museum of London (McPheeters 369). From a very different perspective, the fact that as early as 1581 all the Spanish editions of Celestina were included in the Portuguese Index of Forbidden Books also attests to the popularity of the work in the sixteenth century (McPheeters 374).

The fame of Celestina even reached the Elizabethan England of the Reformation. John Ardila remarks on the editorial success of the work and suggests the date of 1501, year of the arrival of Catherine of Aragon to marry Prince Arthur Tudor and later remarry his brother Henry VIII, as the year of entrance into Britain of the first copies of the book (35). The first translation was published around 1530, although this was actually an adaptation in the form of an interlude that incorporated parts of the prologues and four acts, and turned the work into a comedy by adding a happy ending (Ardila 35). ${ }^{8}$ In accordance with the general trend, Celestina was also more popular in England in the sixteenth rather than the seventeenth century. In his study of the intertextual connections between Celestina and Shakespeare's Romeo and Juliet, Jenaro Artiles points out that in this process of dissemination, the essential element that provided intrigue for

8.- The complete title of the interlude is A New Comodye in English in Manner of an Interlude right elygant \& full of craft of rethoryle/ Wherein is Shewd and Dyscrybyd as Well the Bewte \& Good Propertes of Women/ as Theyr Vycys \& Evyl Codicios/with a Morall Conclusion and Exhortacyon to Vertew. The title reflects the moral undertone of this adaptation that might have been influenced by Juan Vives, who became renowned in the moralist group of Thomas More while teaching at Oxford University. On this point, see Ardila 35 and Artiles 334. The emphasis on women and their vices may have been influenced by the popularity of Vives's De institutione feminae Christianae (1523), a manual of conduct for Christian females, dedicated by Vives to Catherine of Aragon. It is remarkable that Vives' attitude toward Celestina varied dramatically depending on the gender of his audience (he believed women to be more easily influenced than men). For instance, in De institutione he denounces the immorality of such a "liber pestifer» [fetid book] (Ardila 35). On the other hand, in a later work (Disciplina, 1531) he praises the exemplary character of the tragic ending (Snow, «Historia de la recepción» 124-5). 
the reader was not the love affair between Calisto and Melibea -who, unlike Shakespeare's lovers, had no socially insurmountable obstacle to overcome- but rather the figure of Celestina and the intricate scheme she plotted in order to get them involved (329-331). As Maxime Chevalier reminds us, Celestina has become the matchmaker par excellence in Hispanic culture, to the point that her first name has turned into a common noun: the most popular synonym for go-between (142-43). ${ }^{9}$ From a visual standpoint, the old panderer can be identified by her characteristic iconographic attributes (skein of thread, rosary, walking stick etc.). Hence, with the depiction of Celestina, the illustrations have decisively contributed to consolidating her figure as the epitome of the alcahueta in our imaginary. This is also reflected in how the title evolves, giving more prevalence to the figure of the go-between. The 1596 version, published by William Barley, carries the curious title of The Delightful History of Celestina the Faire, which sounds ironic or even parodic. The next version is entitled The Tragicke Comedye of Celestina, published by William Apsley in $1598 .{ }^{10}$

Although the number of editions began to decrease, the export of $\mathrm{Ce}$ lestina continued into the seventeenth century, and the enigmatic figure of the matchmaker continued to travel throughout Europe, blurring the strict borders drawn between the domains of Catholicism and the Protestant Reformation. Two remarkable translations from this century are Kaspar Von Barth's Latin version (1624) and James Mabbe's English rendition (1634). The fact that a book was translated into Latin was a sign of its fame, and elevated that work to the category of a classic (Blanco 26). Published together with the translation, Von Barth added a detailed analysis or dissertatio that Blanco considers the first piece of textual critique on Celestina (26-8). In this commentary, entitled Animadversiones Translatitiae, Von Barth underlines the didactic intention of the work while giving primacy to the figure of Celestina. No wonder the translation is entitled Pornoboscodidascalus Latinus [master of procuress], alluding to Celestina's mastery on the art of matchmaking. Similar to Von Barth's version, Mabbe's translation seems to be presided over by an allegedly edifying intent. Mabbe wrote two translations; the first one (1603-11) was more explicitly moralizing, and, for the mindset of a puritanical seventeenth-century England, was the most politically correct. Ardila wonders if this first translation contained some self-censorship, given that the climate of reformist England of the time was suspicious of any Catholic influence, let alone such obscene and blasphemous readings (38-39). Perhaps this is the reason why in the second version, The Spanish Bawd (1631), which was more faithful to the original, Mabbe signed with the pseudonym «Diego Puede Ser» (Ardila 47).

9.- Maxime Chevalier notes that Juan de Valdés praised Rojas's characterization of Celestina as a «fine matchmaker» (quoted in Chevalier 141 and 143).

10.- See Penney 20. 
In the Spanish editions the figure of Celestina also seems to be progressively taking over the two lovers, to the point that the title of the work and the name of the matchmaker become one. ${ }^{11}$ Similar to the figure of Lazarillo, who became the epitome of the picaro, or that of Quixote, the pursuer of impossible ideals, or Don Juan, the seducer of women, Celestina has become the archetype of the go-between. Overshadowing the unfortunate lovers, as she progressively usurps the title of the work for herself, the image of Celestina increasingly acquires more prominence in the illustrations of the title page.

Unlike other preserved Comedias (Toledo, 1500; Seville, 1501), the 1499 (?) Burgos edition is missing its title page. A close look at the evolution of the title pages, however, will reveal how their illustrations are, if not identical imitations, closely inspired by the illustration of the argumento of the first auto of Fadrique's edition (Fig. 1), showing that this woodcut possibly functioned very early on as a title page and was probably interpreted as such by readers and printers.

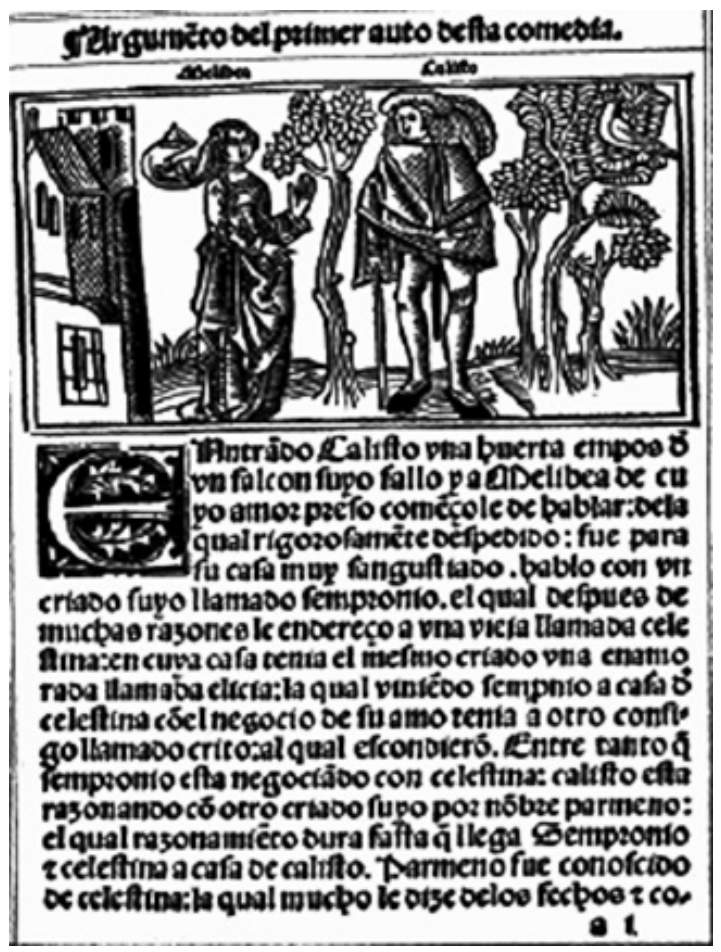

Figure 1. Comedia de Calisto y Melibea. Burgos, Fadrique de Basilea, 1499(?), auto I, fol. a I r. New York, The Hispanic Society of America.

11.- For a detailed account of the titles and designations of the work, see Snow («Historia de la recepción» 117-72). 
In his study of the title pages of Celestina in the sixteenth-century editions, Manuel Abad notes continuity in the woodcuts (47). According to Abad, the title page would portray the scene with essential elements or events from the storyline (48). In this sense, I believe that the first illustration of the 1499(?) edition, although not a title page per se, can be considered as such since it portrays the most important elements of the work and it has been reused as a title page in several later editions. This initial scene of auto I is the most reiterated passage throughout the sixteenth-century illustrated editions (Abad 232). It seems reasonable that this scene would be considered important since it portrays the moment that generates all the action: the encounter between the two lovers in the garden. However, we must note that the inclusion of other characters, mainly Celestina, in that same scene in later title pages seems to indicate an awareness of the increasing importance of the go-between and the servants in the course of events in the story. As Abad explains, the illustrator shows a particular reading experience, offering information about the reception of the written text, even before the illustrations (235). In other words, the illustrator is not working from scratch; he most certainly has seen other illustrations of the work that may have joined his visual repertoire or, using Iser's terms, his own act of reading.

As mentioned above, the scene of the lovers' encounter in the garden, portrayed in the illustration of the first auto of Fadrique's Comedia, is set as a title page in multiple editions; however, the details change, and new characters are introduced. Celestina is first included in the woodcut of the official title page early on: in the 1500 Toledo Comedia. She appears on the left side of the woodcut, leaning on a door and holding her characteristic skein of thread in her hand, while looking out of the corner of her eye at the lovers' first conversation (Fig. 2). The depiction of Celestina in this particular illustration seems to emphasize her age since her face looks extremely emaciated, almost resembling a skull. Perhaps this shows a deeper interpretation of the artist, who may be foreshadowing the destruction that she will eventually bring to the lovers and to the rest of the characters. 


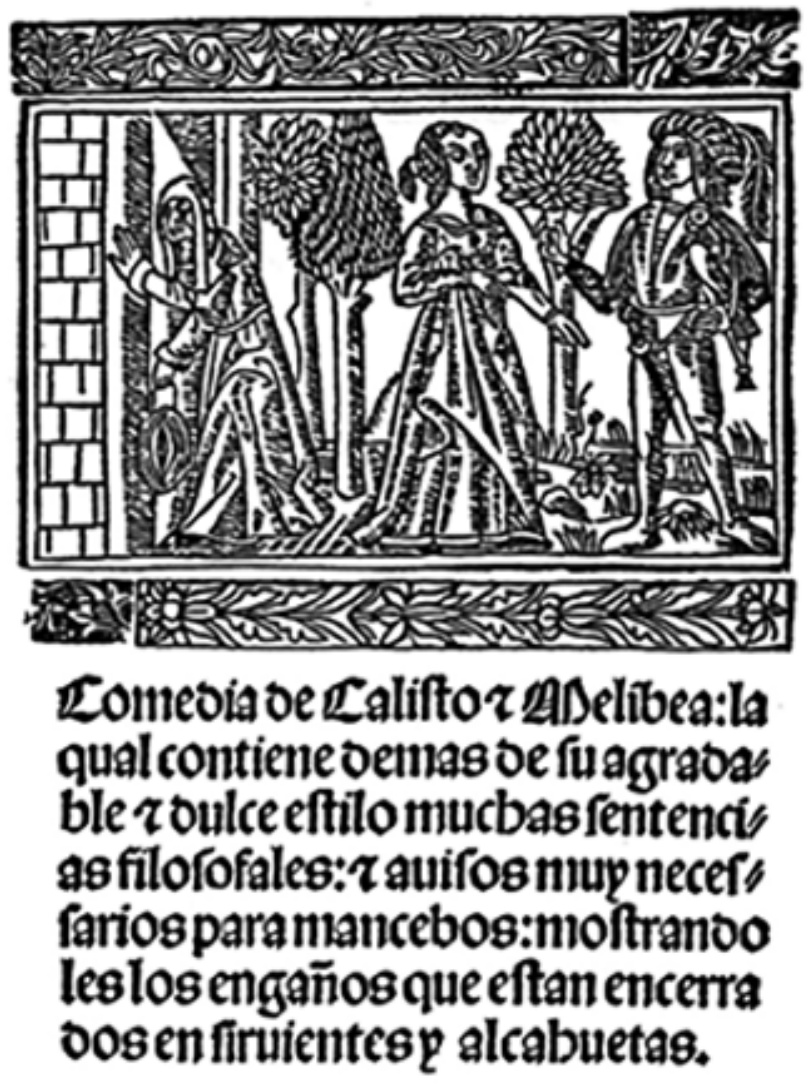

Figure 2. Comedia de Calisto y Melibea. Facsimile of the Toledo, 1500 edition, title page. Geneva, Martin Bodmer Library (reproduced in Penney 95).

More detailed and elaborate, the title page for the 1501 Seville Comedia (Fig. 3), which would be reused for the 1502 Tragicomedia (Fig. 4), depicts Calisto and Melibea in the opening setting of the garden with Lucrecia and a man that might be Sempronio (the abbreviated names of the characters are displayed in captions above them, except for this one). ${ }^{12}$ In the background, in the far left corner of the woodcut, the enigmatic figure of Celestina is facing a closed door and holding the knocker with her right

12.- The detailed elaboration of these title pages renders them more realistic. Moreover, the finely detailed clothing of Calisto and Melibea and the addition of different kinds of ornamental trees in the garden emphasize the wealth of the lovers' households while creating a stark contrast with the sinister figure of Celestina that is lurking behind. Perhaps the illustrator was trying to accentuate the difference in class between the lovers, as well as the nature of Celestina's interest in bringing them together, which was clearly economic. 
hand, while holding a skein of thread in her left hand. ${ }^{13}$ The door, the doorknocker, and the yarn are two important iconographic elements in Celestina. The knocker is the first means of access to Melibea's home, and the yarn that she is selling is the excuse to talk to her. ${ }^{14}$ It is significant that the illustrator gathered all these elements and incorporated them into the title page. By placing these images in the foreground, the illustrator is not just attesting to a particular reception of the written text; he is also attesting to the reception of the previous illustrations, such as those found in the 1499(?) edition, while incorporating the elements considered essential from the perspective of his own conditions of reading. At the same time, this illustrator is constructing the horizon of expectations for future audiences that, logically, will start reading the book by the cover. ${ }^{15}$

13.- It is worth mentioning that subsequent illustrators transformed the elusive black openings in the 1499(?) Comedia into a more detailed depiction of a solid closed door by adding wood panels, jambs, hinges, and nails. One may wonder whether this is intent of controlling the ambiguity of the work, similarly to the punturas inflicted in Rojas's text.

14.- As Manuel Criado de Val has noted, in the Libro de buen amor (1330-43), the word aldaba or altaba had the double meaning of a transversal bar used to secure the door of the house - which would later evolve to mean a knocker - and a go-between, the person who facilitates physical contact between the lovers (24). In fact this is one of the nicknames of the go-between in the Salamanca (S) manuscript (1343). Along the same semantic line, puerta, was a euphemism for vagina, and buena puerta meant an easily accessible woman (Criado de Val 34). Manuel da Costa Fontes has noticed the widespread dissemination of the word hilar and the imagery of sewing (pins, needles, stitches), related to sex and prostitution during the sixteenth and seventeenth centuries in Spanish and Portuguese folk tradition (86-89).

15.- This title page seems to have been tremendously successful, since it was widely reused and imitated with minor modifications in later editions. Stanislao Polono not only used it for his edition of the 1501 Comedia and the 1502 Tragicomedia, but also later on in the Libro de Calisto y Melibea y de la puta vieja Celestina (Seville 1502) and in successive reprints of the Tragicomedia. 


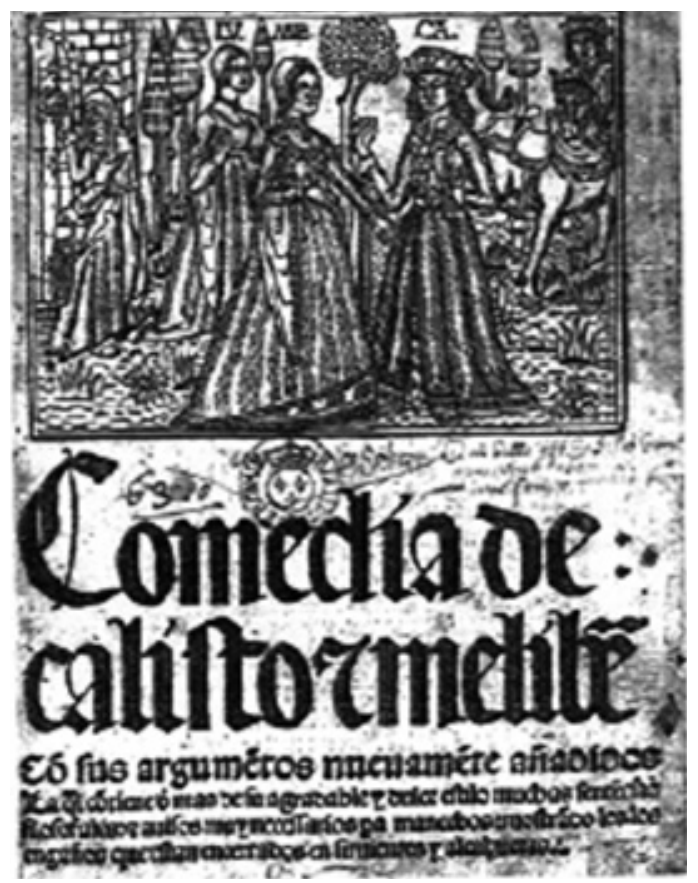

Figure 3. Comedia de Calisto y Melibea. Facsimile of the 1501 edition, title page. Paris, Bibliothèque Nationale (reproduced in Penney 96). 


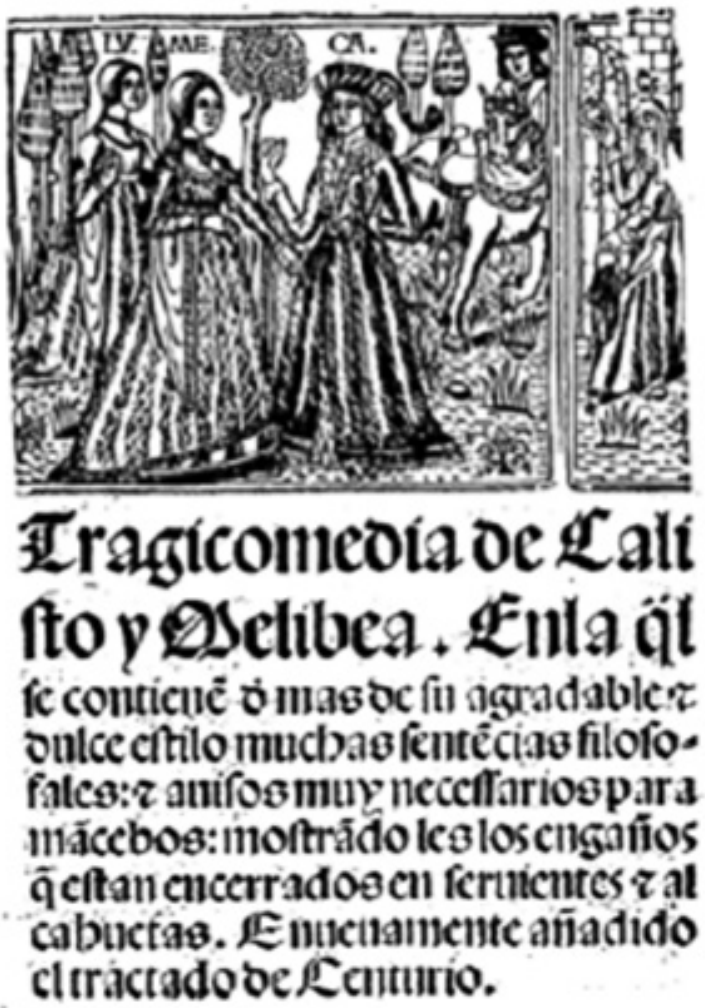

Figure 4. Tragicomedia de Calisto y Melibea. 1502. Title page, fol. a I r. c 20 c 17. London, British Library.

The title page for Remón de Petras's 1526 Tragicomedia (Fig. 5) actually places Celestina in an even more central position, since she appears in the forefront at the door of Pleberio's house. As in previous illustrations, she is holding the doorknocker in one hand and the yarn in the other, in which she is also carrying a walking stick. The main novelty is the long string she is wearing around her neck. It may be the rosary, since it is made of big round beads, but may also be the golden chain Calisto gave her, prompting her death at the hands of the jealous servants. The way the necklace looks, as well as its excessive size, however, remind us of a noose, which may emphasize the connection of Calisto's cadenilla with her violent death. Above the door Celestina is knocking at is a small window through which a woman's head (maybe Lucrecia) is peeking out to look at the matchmaker, who looks back at her, engaging her eyes in complicity. On the left rear side of the woodcut, in a fenced garden, Calisto and Melibea are having an animated conversation, pointing at each 
other with gestures. Calisto carries a big hawk on his left arm, as symbol of his aggressive, predatory masculinity, while Melibea carries a fan, which may be meant to highlight her flirtatious attitude. I believe there is a interesting contrast in the way the lovers and, especially, the woman in the window, are portrayed as enclosed, almost imprisoned, while Celestina wanders free.

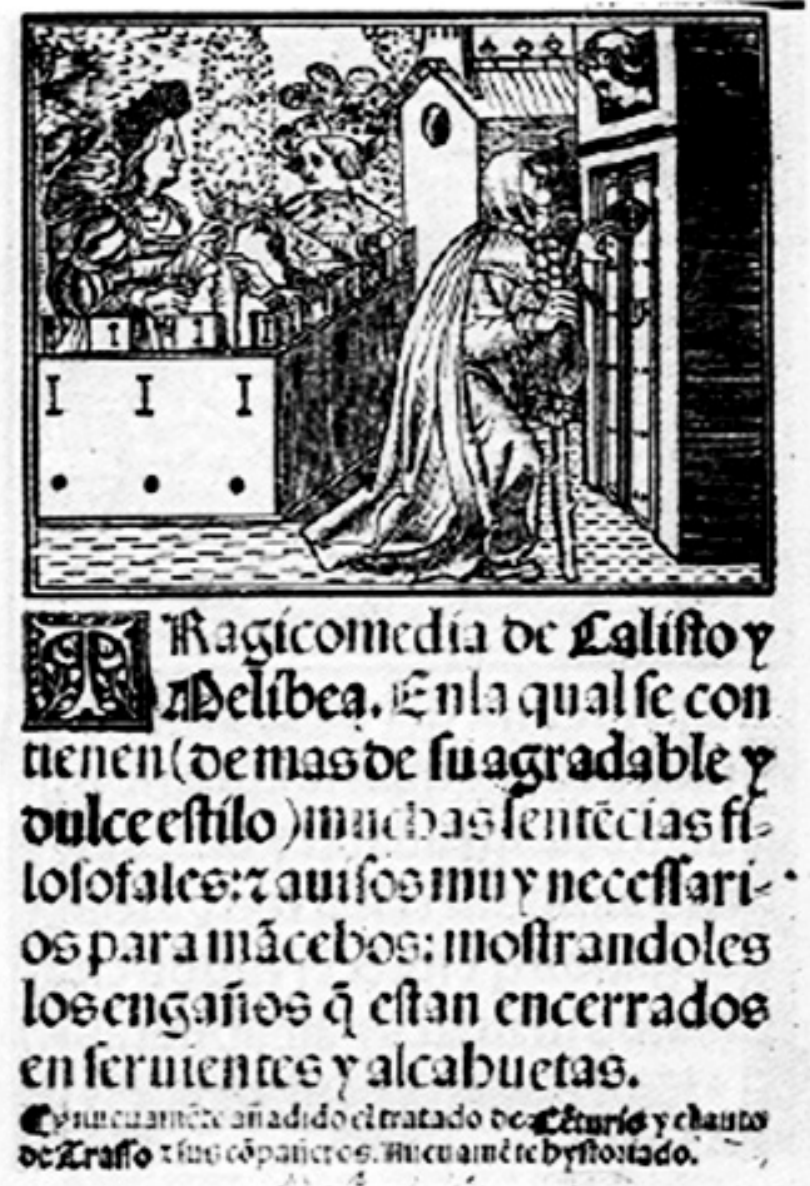

Figure 5. Tragicomedia de Calisto y Melibea. Toledo, 1526, title page, fol. a I r. London, British Library. Shelf mark: 10223.

The title page of Juan Viñao's 1529 Valencia edition seems to give more importance to the figure of Calisto. In this illustration (Fig. 6), the figures of Calisto and his servants are disproportionately larger than Celestina's and the two women who look out from the window of the building. Interestingly, these two tiny female figures in the window look virtually 
identical. One may imagine, judging by the storyline, that they may be Melibea and her maid, Lucrecia. In this scene, it is appropriate to note the width of the window and the women's gestures and body language: standing at the window, with a contemplative air, both displaying serene smiles on their faces and showing their hands to the men outside in a sign of greeting. The window resembles a theater box, and the ladies look like spectators of the show that is taking place below them. ${ }^{16}$ Calisto, in a royal attitude, approaches the house, riding an enormous horse, a symbol of uncontrolled lust. ${ }^{17}$ The stallion is majestically adorned, with a luxurious saddle and a penacho on its head. In this case, the horse clearly underscores Calisto's power and masculinity, reinforced visually by the two servants who walk behind him while a black slave in chains and a dog open the parade. This scene clearly depicts the paraphernalia of a joust. Meanwhile, at the bottom right of the woodcut, Celestina holds the doorknocker. In this particular image, however, it is not completely clear whether she is trying to open or close the door. Her attitude resembles that of a gatekeeper controlling access to the house.

16.- Although to modern readers, the two women might also look like goods on display in a store window, given Celestina's role in "selling» Melibea to Calisto, it is important to consider that this "marketing," since the old go-between also tries to extol the virtues of Calisto to Melibea when she first speaks in his favor to her. 


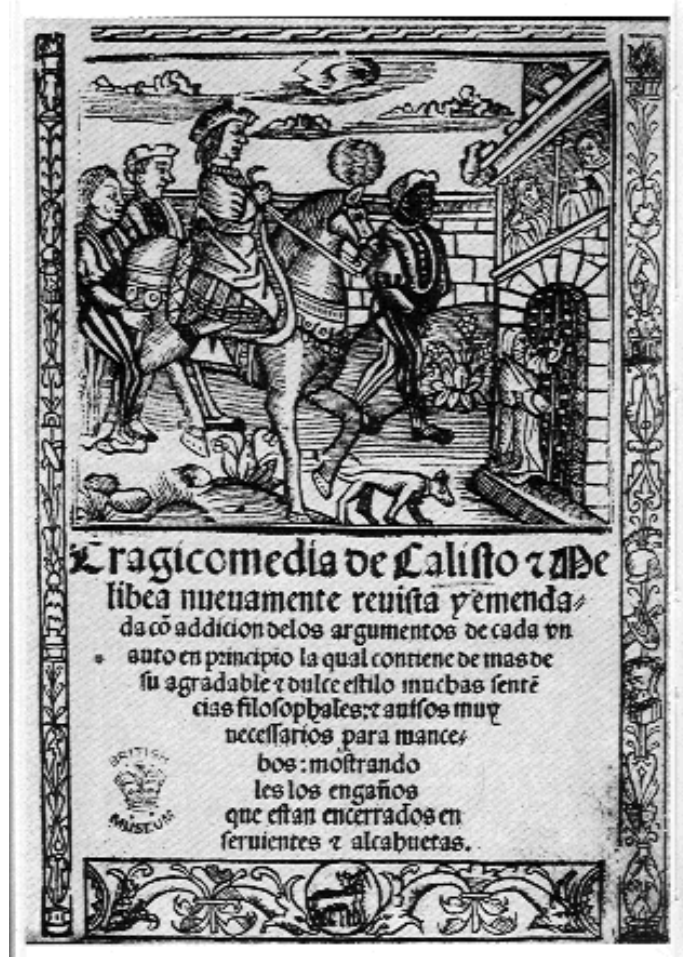

Figure 6. Tragicomedia de Calisto y Melibea. Valencia, 1529, title page, fol. a I r. London, British Library. Shelf mark: c 63 f 25.

The Lisbon title page (1540) is also very peculiar. Instead of in the limits between city and country, Melibea's garden seems to be placed in the middle of town (Fig. 7). In this open urban environment, Melibea appears unusually seductive. Instead of being enclosed, she is sitting on a low wall of her garden, waving her arms as if inviting Calisto to come in. The hawk on his gauntlet, Calisto walks towards her while an aged and rather emaciated Celestina, holding her emblematic skein of yarn and walking stick, watches the scene from the threshold of her house. In this case, the go-between's attitude seems passive and observant. Perhaps the depiction of Melibea in a seductive pose is trying to imply that the procuress did not have much to do to get the lovers together. This type of illustration may suggest a reading, on the part of the illustrator, that underlines Melibea's morally loose conduct, rather than Celestina's tricks, as the main cause of all the misfortunes. 


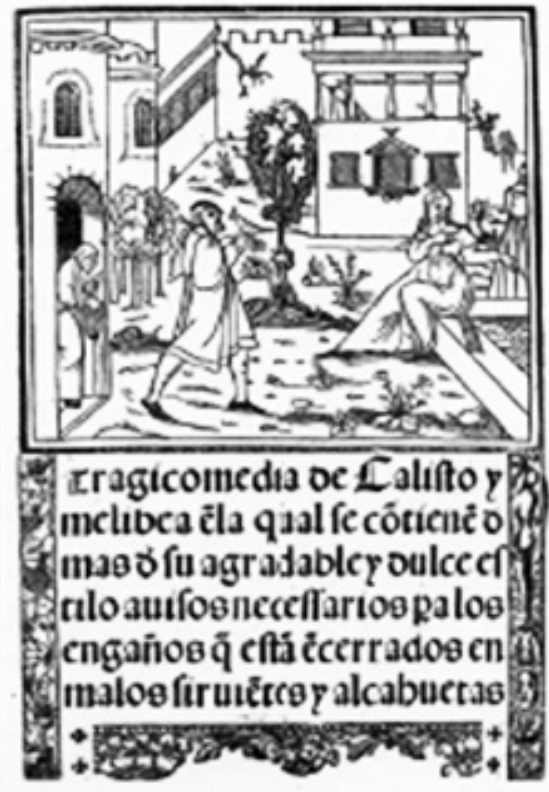

Figure 7. Tragicomedia de Calisto y Melibea. Lisbon, 1540, title page, fol. a I r. London, British Library. Shelf mark: c 20 b 13.

Not all the title pages depict the opening scene of the first auto. In the 1545 Zaragoza edition, for instance, the chosen scene illustrates the moment in which Calisto climbs the wall (Fig. 8). In other cases, the title page is very simple, composed of factotum blocks with the main characters. The 1530(?) Medina del Campo edition, for instance (Fig. 9), portrays just Calisto and Melibea, and even omits any reference to Celestina in the written title. It is significant, however, that on the copy held at the British Museum there is a handwritten inscription added at the top of the page that says "Tragicomedia llamada Celestina,» which shows once again that the work ended up being identified by the name of the go-between In Pedro del Bosque's 1569 Alcalá edition (Fig. 10), there are three characters depicted on the title page (a composite woodcut made of factotums): a man surrounded by two women, one of them most certainly Melibea. The other figure may be Celestina but no specific attributes can confirm this hypothesis. On the other hand, in the case of the first French translation (Paris, 1527), the title page portrays exclusively Celestina, who also gives her name to the title -Celestine (Fig. 11). In this particular portrait, Celestina looks very masculine and defiant, with her arms crossed on her chest and her legs wide apart while her rosary hangs, as a phallus, between them. 


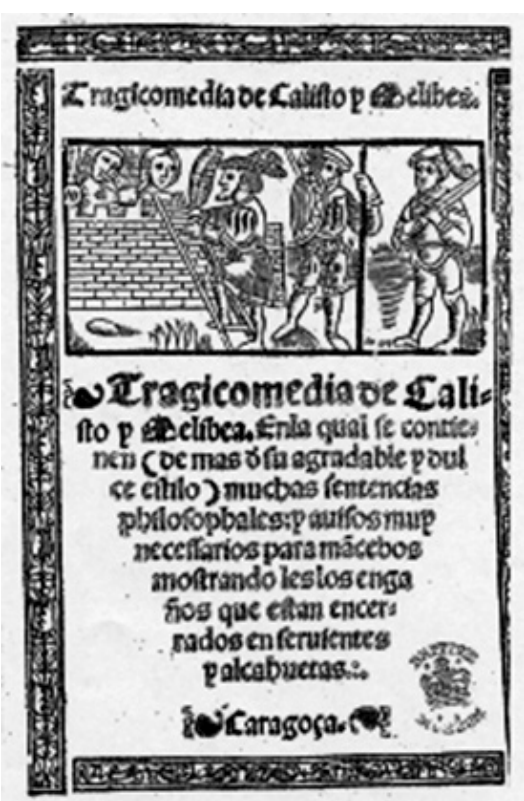

Figure 8. Tragicomedia de Calisto y Melibea. Çaragoça 1545, title page, fol. a I r. London, British Library. Shelf mark: c 63 e 18.

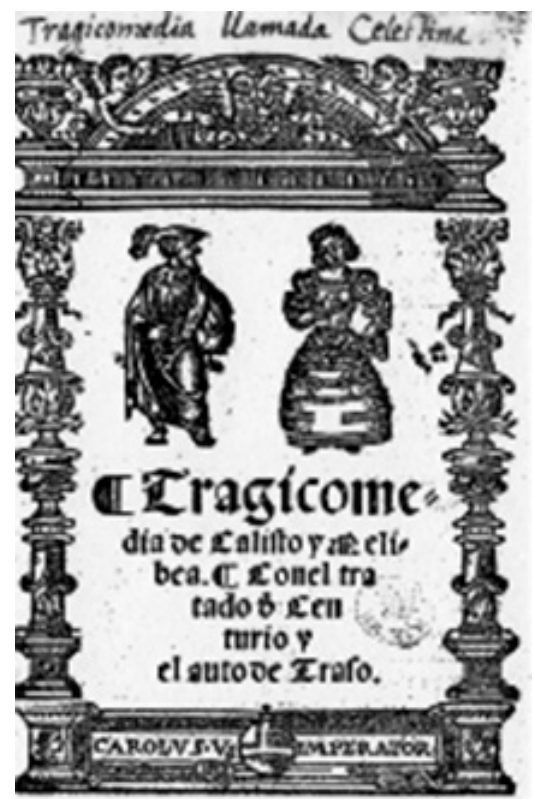

Figure 9. Tragicomedia de Calisto y Melibea. Medina del Campo, 1530 (?), title page, fol. a I r. London, British Library. Shelf mark: 243 a8. 


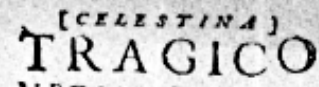

MIEDIA DE CALIS.

toy Melibea, en la qual fe erotio nêde mas de fu agradabley du? ce cflilo muchas fentricias philofophales, $y$ auifos muymeeds farios para mancebos, moltra doles los congaiosque ella encerrados en firuicter y Alchluetus.

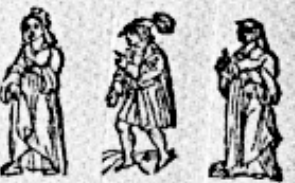

Con licencia imprefta

IN ALCALA

En cafa de Iuan de

Villanueud 1569 .

SAculla de PedrodrlBofquelis bistocuAlcala,

Figure 10. Tragicomedia de Calisto y Melibea. Alcalá, 1569, title page (reproduced in Abad 236).

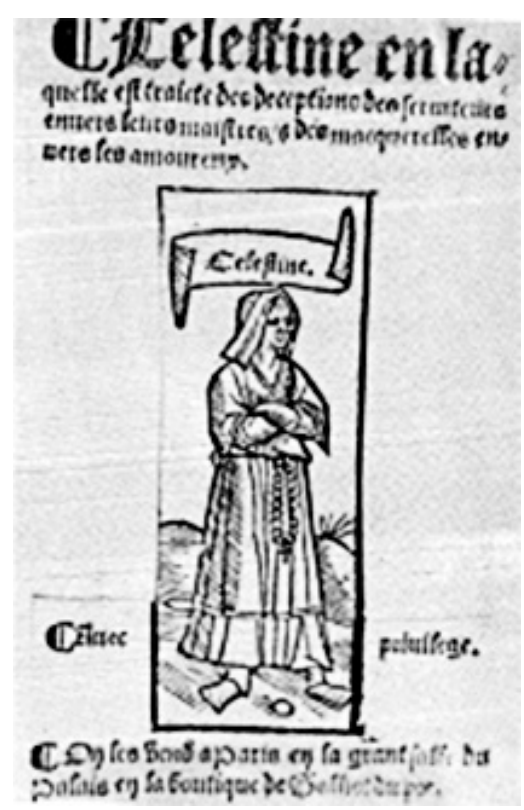

Figure 11. Celestine. Paris, 1527, title page (reproduced in Abad 239). 
These different portrayals, or absences, of Celestina certainly influence the expectations with which the reader approaches the figure of the old matchmaker, and must have doubtlessly contributed to the work's success. I agree with Joseph Snow that a history of the illustration of Celesti$n a$ is in order for a better understanding of the work ("La iconografía" 256). Certainly, such history would take up several volumes if it were to be exhaustive. In the following pages I will just try to give a brief overview, as I have just done with the title page, of how the woodcuts operate in the reception of the work.

The woodcuts for the first known edition were closely modeled on those for Johan Grüninger's 1496 edition of the Comedies of Terence, printed in Strasbourg in 1496 and 1499 (Kelley 191-93). ${ }^{18}$ The influence of the illustrations of the Roman playwright in Fadrique's print shop may have extended beyond the 1499(?) Comedia. Sáinz de Robles points out that after 1496, Fadrique uses woodcut illustrations frequently in his editions (159-60). According to Griffin, this may mean that «early printers and publishers treated it as a drama in the manner of the classical writers of comedy,» therefore underlining the humor present in the book (74). Perhaps, even after that the initial controversy over the tragic or comical quality of the work was resolved, printers continued to use the same models for their woodcuts for aesthetic reasons or because readers became accustomed to them. These woodcuts also have their detractors among scholarly critics. In his study of the splendid illustrations created by Hans Weiditz for the first German translation of Celestina (1520), Jules René Thomé dismisses the woodcuts of the 1499(?) edition as lifeless and lacking in dramatic movement. Furthermore, Thomé labels the illustrations produced at Fadrique's workshop as mere imitations (42). ${ }^{19}$ Certainly, there is an undeniable resemblance in the portrayal of the main characters and their architectural environment; however, the way the illustrations are arranged renders the overall different effect, as Snow has noted. Grüninger's illustrations are composite woodcuts made of stock pieces, in which the factotum figures of the characters alternate with pieces of landscape or architecture. ${ }^{20}$ Snow considers these tacos to be «stereotypes in standing

18.- In the same sense, see Penney 32.

19.- Admittedly, some of Fadrique's woodcuts were reused or repeated in some way in other editions. For instance, the background in the illustration for auto VI of the 1499(?) Comedia is very similar to the one in his edition of the French chivalry book La historia de los nobles caballeros Oliveiros de Castilla y Artús d'Algarbe (printed in May of 1499) and some of the initials seem to have been printed using types from the same block in both editions (Kelley 205). This recycling should not seem surprising or unusual, given that the printer was, after all, an entrepreneur with legitimate business interests and economic limitations.

20.- In fact, Norton states that the use of the factotum blocks (or figuritas) in Spanish woodcuts started with the Comedies of Terence. These figures are stock pieces, each portraying a single character or sometimes even a tree or a house. They were used to indicate the dramatis personae that would play a part in a given play or act. According to Norton, these lateral 
poses, almost never in action» (Snow "The Iconography» 25). Fadrique's woodcuts, on the contrary, are page-width blocks portraying complete scenes where the characters interact and one or more actions take place simultaneously («La iconografía» 259). Snow considers that the page-width simple woodcuts provide a more dynamic and appropriate illustration for the narrative action of the storyline, while giving it a dramatic form. The fact that the same artist fully illustrated the work gives this «visual reading» coherence and continuity ("La iconografía» 260).

Illustrations also served to reinforce the performative quality of the text. As mentioned earlier, while Celestina is not a play strictly speaking, there is an indubitable performative character in the book. Moreover, Isidro Rivera remarks upon not only the performativity but also the theatricality of the work (3). In the study of the reception of Celestina, one must take into consideration the social and cultural circumstances that surrounded the act of reading, such as what Isidro Rivera calls the phenomenon of performance and "prelection.» According to Rivera, the book was read aloud, using gestures and voice inflections, and discussed in small groups. ${ }^{21}$ Of course, when reading out loud, these pre-lectors were conveying their own reading experience by using gestures and intonation. In this oral transmission of the work, the illustrations played an important role because the pictorial narrative of the climactic moments provided visual guidelines as to how to perform «a theatrical context for the representation of Rojas's text» (11-15). In this way, the visual code would act as the frame for the prelection by creating "paratextual links with the concepts and messages communicated by the text» (16). ${ }^{22}$

As explained earlier, the first hint about Celestina's reception might be found in the transformation of the Comedia into the Tragicomedia with the addition of five acts. The woodcuts of the first known Tragicomedia (Seville, 1502) were directly inspired by those in the 1499(?) Comedia, which set the standard for the subsequent editions. ${ }^{23}$ Unlike other woodcut sets, they were created specifically for this edition (Kelley 196).

strip woodblocks were typical of the Spanish loose leaves and would continue to be so until well into the nineteenth century (218).

21.- Rivera argues that Rojas himself offers evidence for these group readings of Celestina, which would not be unusual for pre-modern texts (5-7).

22.- Rivera notes that the factotum blocks of the easy-to-combine lateral strips were more suitable for theatrical representation than the much less versatile, page-width, narrative woodcuts — such as the woodcuts in the 1499(?) edition (12): "the use of factotum blocks in the early decades of the sixteenth century gives Rojas's work a distinctive textual identity. Early modern readers would have been able to make associations between the use of these blocks and the theatricality of Rojas's text» (15).

23.- Penney highlights that Fadrique's edition was so closely followed by subsequent printers (such as Hagenbach or Polono) that they repeated the same typesetting, the same numbering of the chapters (using ordinals until the thirteenth and then cardinals), and even the same spelling mistakes (6). 
According to Penney, they are "the most elegant any edition of Celestina was to know» (31). ${ }^{24}$ Joseph Snow points out that these woodblocks were used over and over again in the various editions, to the point that these tacos became an object of trade and were sold, reused, loaned, imitated, and inherited among the different printers and their successors ("The iconography» 25). In the proto-capitalist market of the printing press, the transmission of the woodcuts of the 1499(?) Comedia was not solely based on artistic reasons. As Snow notes, sometimes a set of blocks could stimulate the sales of an edition and inspire a new set ("The Iconography» 27). This commodification of the woodcuts demonstrates the importance of the illustrations of the 1499(?) edition in the dissemination and publishing success of Rojas's work.

And yet, as mentioned earlier, not all the illustrations reflected the same degree of sophistication. Snow has examined three of the most representative illustrated editions of the first two decades of printing: Burgos 1499(?), Seville 1518, and Valencia 1514, and noted that, compared to the Burgos edition, the Valencia and Seville Tragicomedias have less narrative coherence and are more decorative than illustrative ("La iconografía» 263). ${ }^{25}$ Although both of them are fully illustrated, using one woodcut per auto, following the pattern of the 1499(?) edition, for the most part they used combined factotum blocks rather than pagewidth illustrations. The exceptions are the respective title pages and five newly added non-composite woodcuts, where the same woodcut is repeated for autos XIV and XIX, which depict the two visits of Calisto to Pleberio's house. As previously noted, the inclusion of these page-width blocks is related to the new acts added to the Tragicomedia, which needed more pictorial emphasis than the existing acts, since these were already known to the reader. A downside to the newly added illustrations is that the same block is used for different characters, which creates confusion -especially in the Seville edition. ${ }^{26}$ The economizing and recycling in the woodcuts seems to increase in the successive editions. For instance, Snow's analysis of the first French edition (Paris, 1527) reveals that it is even more visually austere than its predecessors. Faithful to the scheme of the 1499(?) woodcuts, in this edition, illustrations are often placed near the argumentos that begin each auto. Each illustration, however, is reduced

24.- In fact, only three other editions used all blocks cut specifically for them: a German translation (Augsburg 1520), a Flemish translation (Antwerp 1580), and a Spanish edition (Medina del Campo 1582) ("The Iconography» 27). In Snow's view, the only early edition that could compare to Fadrique's, in terms of the quality of its illustrations, is Christof Wirsung's 1520 German translation, illustrated by Hans Weiditz ("La iconografía» 260).

25.- As Snow points out, the other two extant Comedias (Toledo 1500 and Seville 1501) have no illustration except on the title page ("La iconografía» 256).

26.- For an in-depth description of the woodcuts of the Valencia and Sevilla editions, see Snow, «La iconografía» 263-65. 
to pairs of factotum blocks or figuritas repeated arbitrarily, with no connection to the text, which results in unexpressive characters («The Iconography» 28). In order to minimize the predictable confusion that these poor illustrations may cause, the identity of the respective figures is displayed on each character block by using a caption above his or her head. Even with these precautions, confusion becomes unavoidable since these captions are often mistaken and the same block is used to depict different characters. Snow speculates on the reason for the «strange choices for illustration" and this confusion in pairing, which causes the "loss of visual identification of characters» ("The Iconography» 28-33). ${ }^{27}$

Snow wonders why the editions following the 1499(?) Comedia have not improved but rather decreased the aesthetic quality of their illustrations ("La iconografía» 265). Perhaps, I speculate, the success of the work and the constant demand for reprints forced the printers to illustrate them in the fastest, most efficient way. ${ }^{28}$ And, of course, illustrations, even if the quality was not splendid, were a bonus for the marketability of the edition. For example, the Paris edition was intended for a massive distribution in the French market, for an «eagerly awaiting public by its printer-illustrator» ("The Iconography» 34). Conceivably, the rush to produce a new and long awaited edition caused the confusion with the captions that created this amalgam of identities.

As we have just seen, prompted by its editorial success, the more dynamic illustration of the 1499(?) edition gives way to a more static and pragmatic illustration. For Snow, the woodcuts in an illustrated edition represent the individual or collective vision of a contemporary reading and, from a diachronic point of view, signal the existence of an artistic continuity or correlation in the illustrations of the various editions throughout the history of Celestina («La iconografía» 259 and 265). These illustrations constitute a visual «reaction» to the words and therefore are valuable tools to learn about the actual reception of the work, since they provide "clues as ways in which Celestina was

27.- Snow rightly suggests that even with poor resources and few blocks the illustrative scheme could have been much clearer, e.g., using the same stock piece for Celestina, instead of several. A possible but not so plausible explanation would be that both tacos are facing center, but still there would be pages in which this pattern would not be consistent ("The Iconography» 34). Another possibility is that if Melibea's character block is used for Alisa, Lucrecia, Areúsa, and even Celestina, this seems to show a vision of women as undifferentiated on the part of the illustrator; however, even this explanation seems too complicated to make up for the confusion of characters, since male characters are also mixed up. Snow questions if after repeated use, the audience may have been accustomed to this type of non-realistic iconography ("The Iconography» 32). I believe this to be the most viable hypothesis since the pervasive repetition of these otherwise confusing visual schemes would create different pre-conditions for the reader, who would become comfortable with a certain degree of mistaken identity.

28.- On a similar note, Norton reminds us that it was usual for successful editions to experience a progressive compression of the typography in order to shrink the text to the minimum possible volume (216). 
read and understood» («The Iconography» 25). I would add that this reaction is not solely to the written text, but to both word and image, as reflected in the influence of images in the prelection of the work to a group of listeners, as well as by the fact that the five acts added to the Tragicomedia incorporated five new woodcuts, inspired by the blocks of the first known edition of the Comedia.

The first imitation of Celestina is in Pedro Manuel de Urrea's 1513 Cancionero: a versified tribute to the first auto of the Tragicomedia, entitled «Égloga de la tragicomedia de Calisto y Melibea.» Also heavily inspired by Celestina, in 1514 another work by Urrea comes out of Fadrique's print shop: Penitencia de amor, whose title page is illustrated using the opening woodcut for the first auto of the 1499(?) Comedia. ${ }^{29}$ Another work that resuscitates the figure of the go-between is Juan del Encina's Égloga de Plácida y Victoriano (1513). Although matchmaking is not the central theme of this eclogue, one of the characters is an old lady called Eritea - a go-between and midwife who boasts her ability as a hymen mender. Interestingly enough, the illustration on the title page of the Burgos 1518-20 edition by Alonso de Melgar, Fadrique's successor, is precisely the woodcut of the unofficial title page of the 1499(?) edition of the Comedia. ${ }^{30}$

Celestina's literary offspring proliferated during the sixteenth and seventeenth centuries: La picara Justina, by Francisco López de Úbeda (1605); Segunda comedia de Celestina, by Feliciano de Silva (1536), illustrated using the blocks from the 1534 Venice Celestina; La ingeniosa Elena (La hija de Celestina), by Alonso J. Salas Barbadillo (1612); and Tragicomedia de Lisandro y Roselia llamada Elicia y por otro nombre quarta obra y tercera Celestina (Sancho de Muñón, 1542), among others, are descendants of Celestina. Among the works influenced by Celestina we must also mention an outrageous parody: the Carajicomedia. This work was first published in the Cancionero de obras de burlas provocantes a risa (Valencia, 1579) and has been considered a parody of Juan de Mena's Laberinto de fortuna. The influence of Celestina in the Carajicomedia is very explicit: from the very title, literally, "Comedy of the member,» obviously a pun mocking the controversy over Rojas's

29.- Ruth House Webber notes that in the second of the five églogas included in the 1516 edition of Urrea's Cancionero there is an old matchmaker who brags of being "the sister of Celestina.» See Weber 364.

30.- Approaching the work from a narratological perspective, Humberto López Morales considers the influence of Celestina in the Égloga irrelevant and superficial since the presence of the go-between Eritrea seems unnecessary for the main action (317-19). López Morales wonders why Encina decided to include such a poor and useless version of Rojas's alcahueta (321). Nevertheless, given the burlesque tone that pervades the work, one may think that this portrait of the go-between may be parodic. On the other hand, it Encina may have interpreted that the old panderer did not play such an important role in involving the two lovers. In any case, at least for the printer, Alonso de Melgar, there was a connection between the two works, since he chose to use the opening woodcut in the 1499(?) edition of the Comedia de Calisto y Melibea as the title page of Encina's book. 
Tragicomedia, to the central themes of prostitution and matchmaking. Other influences include passages such as the "botica» of the old go-between (copla VII) - a recreation of Celestina's laboratory- or the invocation of the devil (copla XxviII), as well as the claim, in the dedication, that the original poem containing the story was found by the author (43). Celestina's name is in fact mentioned in two coplas (XX and XLVII). ${ }^{31}$ I particularly see a semantic connection on a symbolic level with Rojas's work (and other antecedents of the figure of the go-between, such as the Trotaconventos in the Libro de buen amor) in the use of dysphemic sexual vocabulary. As in the iconography of the woodcuts of Celestina, the doors and the act of crossing the threshold are charged with lewd connotations. The allusions to the "puerta»(55), "puerta muy devota» (83), "portero de la puerta del monasterio" (75), even to the gelosia (86) - which reminds us of the lattice that separate Calisto and Melibea in auto XII of Celestina - bring to mind the dynamics of architectural entrances and bodily openings portrayed in Rojas's work, only that this time is more blatant and even hyperbolic, reflecting a more obviously humorous intention.

Despite the pervasive reuse and dissemination of its illustrations, the editorial practice of illustrating Celestina was discontinued around the middle of the sixteenth century. As Mota has noted, the printing of Celestina declined quite abruptly around 1640, when it was included in the Sotomayor Index, but only seven brief passages were expurgated, and this was for religious reasons. Censorship is another form of reception, but it does not seem plausible to blame censors for the decline of the work's popularity. Strangely enough, as Mota points out, Celestina did not experience many problems from the Inquisition. The text was not banned until 1793, when the reason given was alleged obscenity. The work was not printed again until 1822, but by that time its popularity had decreased substantially (Mota 43-44). During the nineteenth and early twentieth centuries, Celestina's editions generally lack illustrations (Snow "The Iconography» 27). Most likely, the disappearance of the illustrations happened during a period in the history of literature in which images in general became less important as the written word moved to the center of the reading experience. Even without the presence of the illustrations, but undoubtedly due to their previous presence, especially in the influential 1499(?) edition, the figure of Celestina is permanently ingrained in our imaginary and in our language, giving a female name to the act of transgression.

31.- There is even a reference to the infamous puntadas that Rojas complains about in the prologue of the Tragicomedia but, in this case, with different connotations and in a clearly sexual context: when a groom, after unsuccessful attempts to penetrate a woman, whose hymen had been tightly sewn by an old go-between, decides to light a candle and inspect the alleded virgin, «vido dadas crueles puntadas en los beços del coño. Los cuales cortando, con gran dolor de la novia, luego le fue por misterio de los dioses abierto un grandísimo piélago...» (84). Interestingly, under the grotesque hyperbole of this moment, there is a patriarchal unveiling of the fiction Celestina embodied. 


\section{Works Cited}

ABAD, Manuel. «La ilustración de portadas de La Celestina, en siete ediciones del siglo XVI.» Revista de Ideas Estéticas 35 (1977): 229-38.

ArdilA, John G. "Una traducción 'políticamente correcta': Celestina en la Inglaterra puritana.» Celestinesca 22.2 (1998): 33-48.

Artiles, Jenaro. "La Celestina y Romeo y Julieta.» La Celestina y su contorno social : Actas del I Congreso Internacional sobre La Celestina. Ed. Manuel Criado de Val. Barcelona: Borrás Ediciones, 1977. 325-38.

BARBERA, Raymond. "Medieval Iconography in the Celestina.» Romanic Review 61 (1970): 5-13.

Blanco, Emilio. "Algunas notas sobre la recepción de Celestina en los siglos XVI y XVII.» Celestina: Recepción y herencia de un mito literario. Ed. Gregorio Torres Nebreda. Cáceres: Universidad de Extremadura, 2001. 17-49.

Carajicomedia. Ed. Alonso Álvar. Archidona (Málaga): Ediciones Aljibe, 1995.

CHeValier, Maxime. Lectura y lectores en la España de los siglos XVI y XVII. Madrid: Turner, 1976.

Costa Fontes, Manuel da. "Fernando de Rojas, Cervantes, and Two Portuguese Folk Tales.» Hispanic Medieval Studies in Honor of Samuel G. Armistead. Eds. E. Michael Gerli and Harvey L. Sharrer. Madison, WI: Hispanic Seminar of Medieval Studies, 1992. 85-96.

Criado de Val, Manuel. Diccionario de Español Equívoco. Madrid: EDI-6, 1981.

Encina, Juan del. Égloga de Plácida y Victoriano. Teatro completo. Ed. Miguel Ángel Pérez Priego. Madrid: Cátedra, 1991.

Folger, Robert. Images in Mind: Lovesickness, Spanish Sentimental Fiction and Don Quijote. Chapel Hill: U of North Carolina P, 2002.

Grifrin, Clive. "Celestina's Illustrations.» Bulletin of Hispanic Studies 78 (2001): 59-79.

HerriotT, J. Homer. Towards a Critical Edition of the Celestina; a Filiation of Early Editions. Madison: U of Wisconsin P, 1964.

ISER, Wolfgang. "Interaction between Text and Reader." The Reader in the Text. Essays on Audience and Interpretation. Ed. Susan R. Suleiman and Inge Crosman. Princeton: Princeton UP, 1980. 106-19.

Jauss, Hans R. Toward an Aesthetic of Reception. Trans. Timothy Bahti. Intro. Paul de Man. Minneapolis: U of Minnesota P, 1982.

Kelley, Erna Berndt. "Mute Commentaries on a Text: The Illustrations of the Comedia de Calisto y Melibea.» Fernando de Rojas and Celestina: 
Approaching the Fifth Centenary. Eds. Ivy A. Corfis and Joseph T. Snow. Madison, WI: Hispanic Seminary of Medieval Studies, 1993. 193-227. López Morales, Humberto. "Celestina y Eritrea: La huella de la Tragicomedia en el teatro de Enzina.» La Celestina y su contorno social: Actas del I Congreso Internacional sobre La Celestina. Ed. Manuel Criado de Val. Barcelona: Borrás Ediciones, 1977. 315-23.

McPheeters, Dean W. «La Celestina en Portugal en el siglo XVI.» La Celestina y su contorno social : Actas del I Congreso Internacional sobre La Celestina. Ed. Manuel Criado de Val. Barcelona: Borrás Ediciones, 1977.

MotA, Carlos. "La Celestina de la imprenta de Fadrique de Basilea.» Actas de las jornadas "Surgimiento y desarrollo de la imprenta en Burgos" (De la Ars Grammatica de A. Gutiérrez de Cerezo a La Celestina de Fernando de Rojas). Ed. Marco A. Gutiérrez. Burgos: Instituto Municipal de Cultura (Ayuntamiento de Burgos), 2000. 41-58.

NORTON, Frederick J. La imprenta en España: 1501-1520. Trans. Daniel Martín Arguedas. Madrid: Ollero \& Ramos, 1997.

Penney, Clara L. The Book Called Celestina in the Library of the Hispanic Society of America. New York: The Hispanic Society of America, 1954. RIVERA, Isidro J. "Performance and Prelection in the Early Printed Editions of Celestina.» Celestinesca 22.2 (1998): 3-20.

Rojas, Fernando de. Comedia de Calisto y Melibea. Burgos, 1499. Facs. New York: Hispanic Society of America, 1909. Rpt. in La Celestina: Two Facsimiles (1499? and 1528). Facs. New York: Hispanic Society of America, 1995.

—. La Celestina. Ed. Dorothy S. Severin. Madrid: Cátedra, 2000.

SÁINZ DE Robles, Federico C. La imprenta y el libro en la España del siglo XV. Madrid: Vasallo de Mumbert, 1973.

Snow, Joseph Thomas. "The Iconography of the Early Celestinas, I: The First French Translation (1527).» Celestinesca 8.2 (1984): 25-40.

-. "La iconografía de tres Celestinas tempranas (Burgos, 1499; Sevilla, 1518; Valencia, 1514): Unas observaciones.» Dicenda. Cuadernos de Filología Hispánica 6 (1987): 255-277.

—. "Hacia una historia de la recepción de Celestina: 1499-1822.» Celestinesca 21 (1997): 113-73.

Thomé, J.R. «Hans Weidtz (Johannes Giudictius): Primer ilustrador dramático de La Celestina.»Cuadernos de Bibliofilia (1979): 41-50.

WebBer, Ruth House. «Pedro Manuel de Urrea y La Celestina.» La Celestina y su contorno social: Actas del I Congreso Internacional sobre La Celestina. Ed. Manuel Criado de Val. Barcelona: Borrás Ediciones, 1977. 359-66.

Whinnom, Keith, "The Problem of the 'Best-Seller' in Spanish GoldenAge Literature.» Medieval and Renaissance Spanish Literature: Selected Essays. Ed. Alan Deyermond, W.F. Hunter, and Joseph T. Snow. Exeter: U of Exeter P with the Journal of Hispanic Philology, 1994. 159-75. 



\title{
Montero, Ana Isabel, «Reading at the Threshold: The Role of Illustrations in the Reception of the Early Editions of Celestina», Celestinesca 39 (2015), pp. 197-224.
}

\section{RESUMEN}

Ya sea en su formato original de Comedia en dieciséis actos publicada por primera vez alrededor de 1499, o en su posterior encarnación en la Tragicomedia de 1501, las numerosas ediciones y traducciones que circularon durante el siglo XVI ponen de manifiesto la enorme popularidad y el profundo impacto literario de Celestina a lo largo de Europa. Se han escrito estudios incontables sobre la recepción de Celestina desde el siglo XV hasta el momento presente. Sin embargo, no se ha dicho mucho sobre la influencia de los grabados de la primera edición conocida en el éxito de la obra: ¿Cómo los interpretaron los lectores? ¿Fueron las ilustraciones tomadas en cuenta por los editores e ilustradores de las ediciones sucesivas? Este artículo explorará la importancia de los grabados en la difusión y el éxito editorial de la obra de Rojas, así como en la creación y divulgación de la saga inmortal de Celestina, reencarnada de modo incesante gracias a la imprenta.

PALABRAS CLAVE: Ilustraciones de la Celestina, xilografías, recepción.

\begin{abstract}
Whether in its original form, a Comedia with sixteen acts first published around 1499, or in its later incarnation in the 1501 Tragicomedia, the numerous editions and translations that circulated during the sixteenth century bear witness to Celestina's widespread popularity and profound literary impact all over Europe. Countless scholarly studies have been written on the reception of Celestina from the fifteenth century to the present time. Not much has been said, however, about the influence of the woodcuts of the first known edition in the success of the work: How did the readers interpret them? Were the illustrations really taken into account by the editors and printers of the successive editions? This article will explore the importance of the woodcuts in the diffusion and publishing success of Rojas's work as well as in the creation and propagation of the immortal saga of Celestina, reincarnated incessantly thanks to the printing press.
\end{abstract}

KEY WORDS: Illustrations of Celestina, woodcuts, reception.

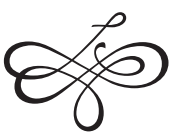

